\title{
Geomorphology and Evolution of the Modern Mahanadi Delta Using Remote Sensing Data
}

\author{
K. Somanna ${ }^{1}$, T. Somasekhara Reddy ${ }^{2}$, M. Sambasiva Rao ${ }^{3}$ \\ ${ }^{1,2,3}$ Dept. of Geography, Sri Krishnadevaraya University, Anantapuramu, Andhra Pradesh, India
}

\begin{abstract}
The Mahanadi delta covering an area of about 7,500km has been studied using aerial photographs on scale 1:31,680 and Geocoded data on scale 1:50,000 with a view to delineate the landforms and lineaments. Based on geomorphic process and agents the landforms are classified into fluvial, fluvio- marine and marine. The Mahanadi delta is dominated by fluvial processes. The delta is formed of a number of abandoned river courses. The landforms formed due to coastal processes are later disturbed by the fluvial processes. Based on disposition of old and abandoned river courses about 23 abandoned meander lobes are identified. Basing on disposition of ancient beach ridges three major strandlines/former delta fronts are recognized. The morphological growth of the modern Mahanadi delta has been described basing on disposition of abandoned meander lobes and ancient strandlines. There are about 20 macro lineaments which have directly or indirectly have affected the landforms and the growth of the delta. A few geomorphic highs are morpho-structures are identified by tonal contrast relief, shape, vegetation, meandering of former and present river courses. The rate of progradation of the modern Mahanadi delta is about $9.1 \mathrm{~km}$ for one thousand years. The modern Mahanadi delta might have been formed during the Holocene period.
\end{abstract}

Keywords: fluvial and coastal processes, abandoned river courses, ancient beach ridges, lineaments

\section{Introduction}

Deltas of the east coast of India are formed of both fluvial and coastal landforms. The geology, relief, catchment area, gradient, hydro-dynamics and rate of sedimentation play a significant role in formation of deltas. Fluvial dominated landforms are formed when fluvial processes predominate over coastal processes and vice versa. Bagchi ${ }^{5}$ has described the different features of Hooghly delta and has divided the delta into three major units as "moribund", ,mature and „old"e. Morgan and Mc. Intire ${ }^{13}$ have studied the Quaternary geology of the Bengal provinces of East Pakistan (Now Bangladesh) and India and concluded that structural activity and primary faulting have significantly influenced the Quaternary geology of the Hooghly delta. Niyogi ${ }^{17}$ has brought out the evolution of Subernarekha delta from a study of aerial photographers on scale 1:50,000. $\mathrm{Babu}^{3,4}$ has explained the geomorphic features of Krishna and Godavari deltas and has traced the evolution of Krishna delta basing on disposition of ancient channels and beach ridges. Nageswara rao and Vaidyanadhan ${ }^{14}$ have studied the landforms of the Krishna delta and traced its evolution. Sambasiva $\mathrm{RaO}^{20}$ has studied the geomorphology and evolution the modern Godavari delta basing on disposition of abandoned meander lobes and strandlines. Sambasiva Rao etal. ${ }^{23}$ have mapped the morphological features of Mahanadi and Brahmani-Baitarani deltas and traced their evolution. Sambasiva Rao and Vaidyanadhan ${ }^{24}$ have mapped the landforms of the Godavari delta and described the different stages in the growth of modern delta basing disposition of ancient channels and beach ridges. Sambasiva $\mathrm{RaO}^{21}$ has explained the morphology and evolution of modern Cauvery delta, Tamil Nadu using aerial photographs on scale 1:50,000 and LANDSATS (1:250,000). The geomorphology and evolution of the Pennar delta has been described by Sambasiva Rao and Lakshminarayana ${ }^{25}$. The BrahmaniBaitarani delta geomorphology and evolution has been explained by Sambasiva Rao ${ }^{22}$.

\section{Study Area}

The Mahanadi delta covering an area of about 7,500 $\mathrm{km}^{2}$ lies along the east coast of India in Odessa state between $19^{0} 14^{1}$ to $20^{0} 33^{1} \mathrm{~N}$ latitude and $85^{\circ} 45^{1}$ to $86^{\circ} 47^{1} \mathrm{E}$ longitude. The arcuate shaped Mahanadi delta has a coastline of about $190 \mathrm{~km}$ extending from Puri in the south to Hatikola spit in the north. The drainage basin area of the Mahanadi river is about $115,000 \mathrm{~km}^{2}$. The Mahanadi river has its origin at an altitude of about 825 meters above MSL over Pasasagaon pleatue (Dhandakaranya) and flows for about $680 \mathrm{~km}$ before entering into the apex of Mahanadi delta near Cuttack. The Mahanadi delta is bordered by Mio-Pliocene sandstone lateritic up lands. The river Mahanadi debouches into Bay of Bengal through two major distributaries namely Mahanadi river and Devi river. The Daya, Bhargavi, Kushbhandra and Prachi Nadi are other minor distributaries.

\section{Objectives}

The main objectives of the study area are:

1) To map the landforms of the Mahanadi delta using aerial photographs and remote sensing data.

2) To study the lineaments and the effect of lineaments on the landforms and

3) To bring out the stages in the growth of the Mahanadi delta basing on disposition of abandoned meander lobes and strandlines.

\section{Methodology}

The aerial photographs on scale 1:31,680 and Geocoded data on scale 1:50, 000 and LISS III data are studied basing on gray tonal variations, alignment parallel to river courses and coastline, texture, size and shape. Various landforms identified and mapped from the study of air photos and Geocoded data are transferred on Survey of India base maps of $74 \mathrm{E}, 73 \mathrm{H}, 73 \mathrm{~L} \& \mathrm{P}$ and $74 \mathrm{I}$ on scale $1: 250,000$. Field checks are carried out to identify the landforms identified 


\section{International Journal of Science and Research (IJSR) \\ ISSN (Online): 2319-7064}

Index Copernicus Value (2013): 6.14 | Impact Factor (2014): 5.611

from the study of air photos and Geocoded data. The lineaments are identified basing on alignment of river courses, water bodies, tonal variations and deformation in the formation of landforms. The direction and length of lineaments are worked out. Basing on disposition of anastamosing abandoned river courses, the abandoned meander lobes and paleo confluences are traced. Basing on the direction, orientation and altitude of beach ridges the ancient coastlines (strandlines) are identified. Finally basing on disposition of abandoned meander lobes and strandlines the stages in the growth of delta fronts are interpreted and the overall growth of delta is discussed.

\section{Morphology of the Mahanadi Delta}

The major landforms of the Mahanadi delta are classified into fluvial, fluvio-marine and coastal basing on geomorphic process and agents involved in their formation. The fluvial landforms are ancient/old channels, natural levees, fossil islands and river islands. The fluvio-marine landforms are paleo-confluences and paleo lagoons, marshes, mudflats and mangroves. The coastal landforms are beach ridges, coastal sand dunes, spits and lagoons. (Figure 1)

\section{Fluvial landforms}

The fluvial landforms are formed in the delta by river action. The ancient channels or old channels are low lying plains on the present delta. They are identified by dark tonal contrast, relative relief and alignment parallel to the present river courses. The ancient channels are subjected to floods during monsoon periods. The anastamosing nature of old channels with a number of cutoffs and fossil islands show successive changes in the old river courses as delta prograded. To a large extent the geology, topography and gradient of the basin determine the changes in the river courses as delta prograded. It is found that majority of old river courses bifurcated near to the apex of the Mahanadi River in the Mahanadi delta. After bifurcation the gradient, hydrodynamics, Neo-tectonics, rate of sedimentation, the bottom topography, fluvial and coastal processes play a major role to determine the active deposition of deltaic sediments. Later, the old river courses or abandoned river courses are slowly filled up by the sediments brought by river during monsoon and flood periods. According to Sambasiva Rao and Vaidyanadhan ${ }^{24}$ a group of ancient or old channels in an abandoned meander belt is considered to represent a major abandoned distributary that debouched into Bay of Bengal during a certain period of the growth of the delta. About 23 major abandoned river courses have been traced basing on disposition and waving nature of ancient channels in each stage of growth of the Mahanadi delta. Wright and Coleman ${ }^{28}$ described that configuration of landforms suits characteristics of any given delta depend to a considerable degree on wave power adjacent to the shore and on the river discharge relative to river forces. River dominated shoreline configuration result only when river is able to build up flat off-shore profiles like Mississippi river, and the shore dominated deltas are built up when wave action is dominating over fluvial action like Subranarekha delta. In the Mahanadi delta the fluvial processes are dominating over coastal processes and therefore fluvial dominant delta is built up. There are about 23 abandoned paleo-confluence points in the Mahanadi delta.
The River Devi and River Mahanadi have developed natural levees parallel to their courses on either side of the bank. They can be recognized by tonal contrast, relief and proximity to the river courses. They are fine silts deposited during flood periods. Bagchi ${ }^{5}$ reported such natural levees formation along the Hooghly river in the Ganges delta and described that they are formed due to seasonal accretions during flood periods.

The abandoned river courses during their period of active deposition have deposited a few river islands in their courses. The river islands stand prominently and relatively high in the abandoned river courses. They are recognized by relief, tone and their location in the old river courses.

In the present River Devi and River Mahanadi course, a few river islands have been deposited by the fluvial process during monsoon and flood periods. Their accretion has taken place slowly over a long period of time during flood periods. The relief, gradient, hydro-dynamics, rate of sediments and off shore topography determine the formation of river islands in the active river courses. They are recognized by relief, gray tone and location in the active river courses or distributaries of the Mahanadi delta.

\section{Fluvial-marine landforms}

The fluvio-marine landforms are paleo confluences, paleo lagoons, marshes, mudflats and mangroves. About 23 paleo confluences and paleo lagoons are identified. The paleo confluences are the former river courses confluence points with the then sea. Each abandoned river course has one paleo confluence and one paleo lagoon. The paleo lagoons are former filled in lagoons with both fluvial and marine sediments and are located near to the former confluence points. They are recognized by gray tone, relief and location parallel to the former shorelines.

The marshes and mud flats are located near to the present shoreline. During high tide saline water enters into the marshes and mudflats. The marshes and mudflats ate located north and south of Devi river confluence point. They are identified by their location parallel to the present shoreline, low relief, grassy vegetation and gray tone.

The mangroves are located in the north and southern bank near to Mahanadi river confluence point. They are alkaline clayey soils and are covered with mangrove trees which are dwarf in height. Both marine and fresh water fish and prawn are available in this zone. They are flooded during flood periods and high tide period. The drainage is anastamosing with meandering tidal creeks. They are good fluvio-marine ecosystems. They are identified in the aerial photographs by their alignment parallel to parallel to the coastline, vegetation, relief, drainage and gray tone.

\section{Coastal Landforms}

The coastal landforms are formed by marine processes by wave action. The prominent features are ancient beach ridges. They are low sandy ridges lying parallel to the shoreline deposited by wave action. A series of beach ridges are deposited in the Mahanadi delta as the growth of delta has taken place. The variations in spacing, width and 


\section{International Journal of Science and Research (IJSR) \\ ISSN (Online): 2319-7064 \\ Index Copernicus Value (2013): 6.14 | Impact Factor (2014): 5.611}

direction of beach ridges indicate changes in coastal configuration. Some of the beach ridges are disturbed and washed away by later fluvial processes.

Basing on spacing, direction, number and width of beach ridges about three strandlines have been identified. A strandline shows a group of approximately parallel beach ridges formed during a certain period of time of the growth of delta. The beach ridges in the Mahanadi delta lie parallel to the present shoreline. The first series of beach ridges are found near Ghordia at a maximum distance of about $35 \mathrm{Km}$ from the shoreline. The number of beach ridges are 3 to 5(Table 1). The width of the belt of beach ridges is about $3 \mathrm{Km}$. The direction of beach ridges is $\mathrm{E}-\mathrm{W}$ and height varies from 5.5 to 8.2 meters above MSL. The second series of beach ridges are located NW of Puri at a distance of about $19 \mathrm{Km}$ from the present shoreline. The number of beach ridges varies from 4 to 6 and the width is about $5 \mathrm{Km}$. The direction of beach ridges is ENE-WSW. The third series of beach ridges are located at a distance of $7 \mathrm{Km}$ from present shoreline. They are located in and around Puri and Konark. The number of beach ridges varies from 5 to 8 and the average width is about $7 \mathrm{Km}$. They lie parallel to present shoreline in E-W and ENE -WSW direction. The altitude varies from 1.5 to 4.5 meters above MSL. Beach ridges are also found in between River Devi and River Mahanadi and in between River Mahanadi and River Brahmani and River Baitarani.

Along the present shoreline sand dunes are deposited by wind action from the dry sands of beaches during low tide. The width of the sand dunes vary from 500 meters to 2,500 meters. The texture of sands vary from fine to medium and coarse. The altitude of dunes vary from 0.5 meters to 2.5 meters. The dunes are covered with "Spinifex Littoreus" maritime spiny and bushy grasses.

A prominent spit is formed north of confluence point of River Mahanadi. The spit runs to an extent of about $25 \mathrm{Km}$ length in north-south direction. The width of the spit varies from 200 meters to 500 meters. It looks like a hook for about $10 \mathrm{Km}$ from the confluence of River Mahanadi and the direction of formation is NE-SW. Later the spit grew northsouth for about $15 \mathrm{Km}$. The spit is formed by the deposition of sediments brought by littoral currents. Behind the spit a lagoon is formed. The spits are also noticed at the confluence of River Devi. These spits are smaller in size and change according to the littoral currents direction.

\section{Lineaments}

About 20 macro lineaments have been traced from the study of aerial photographs, Geocoded data and false colour composites basing on tonal contrast, vegetation, alignment of streams, initiation of meanders and sudden changes in river courses. About 13 lineaments align east-west and north-east to south-west. The cumulative length of thirteen macro lineaments is $434.70 \mathrm{Km}$ (Table 2). About seven macro lineaments align north to south, north north- west to south south-east and north-west to south-east. The cumulative length of seven macro lineaments is $235.50 \mathrm{Km}$. The total cumulative length of twenty macro lineaments is $670.20 \mathrm{Km}$. The lineaments did participate in changing the river courses. The River Devi is maintained NNE to SSW direction by a macro lineament extending to a length of about $60 \mathrm{Km}$. Similarly the River Mahanadi is controlled by a macro lineament extending west north-west to east southeast extending to a distance of about $51.50 \mathrm{Km}$. Another macro lineament aligning NNW-SSE extending to a length of about $42.85 \mathrm{~km}$ is controlling the course of River Devi. The effect of lineaments on the natural levees is insignificant. A macro lineament extending to a length of $240 \mathrm{~km}$ aligning northeast to southwest direction has affected the disposition of landforms and sediments. The depth of sediments below the macro lineament has extended up to 3.5 to $4 \mathrm{~km}$. some of the abandoned river courses are also controlled by macro lineaments. A macro lineament aligning east-west direction extending to a length of about $62 \mathrm{~km}$ has controlled the former river course north of Kendrapara. Another macro lineament west of Devi River has effected on the disposition of abandoned river courses and sediments deposited. One macro lineament extending to a length of about $32 \mathrm{~km}$ in north-east to south-west direction seem to have passed through the mangroves north of River Mahanadi and controlling the tip of spit formed in the Bay of Bengal. By and large the effects of macro lineaments are noticed on the landforms of the Mahanadi delta. In the Precambrian craton majority of the lineaments are faults and fractures. Some of the macro lineaments might have formed during the growth of the delta due to coalescence of sediments along certain directions and some of them might have been formed due to rejuvenation of faults of underlying rocks.

\section{Geomorphic Highs}

A geomorphic high or morphostructure consists of earth 's surface which is produced by interaction of exogenetic and endogenetic forces in which the endogenetic forces is dominating over exogenetic force. In general it is an actively developing element due to tectonic movements during the latest geological times namely Neogene and Quaternary periods (Fairbridge ${ }^{8}$ ). The geomorphic highs or morphosturctures are identified by tonal contrast, relief, oval or rounded shape, vegetation and meandering of former river courses and present river courses. In the first stage of growth of delta one geomorphic anamoly or high is found east of Ghordia. About nine geomorphic highs or morphostructures are noticed in second phase of growth of the delta. In the third phase of growth of delta about six morphostructures are identified in the Mahanadi delta. The geomorphic highs are formed on the delta plains. Neither the former or abandoned river courses or present river courses have cut across the morphostructures. Further geophysical studies of these geomorphic anamolies or highs may throw light upon occurrence of oil and gas beneath these morphosturctures. Similar geomorphic anamolies or highs are identified in other deltas of the east coast of India by $\mathrm{Babu}^{1,2,3,4}$, Nageswara Rao and Vaidyanadhan ${ }^{14}$, Sambasiva Rao etal. ${ }^{23}$, Sambasiva Rao and Vaidyanadhan ${ }^{24}$, Sambasiva Rao ${ }^{21}$. Based on studies of morphostructures of Krishna and Godavari deltas $\mathrm{Babu}^{2}$ concluded that the trend of the anamolies follow the structural trend of Eastern Ghats which are located further inland. The occurrence of geomorphic highs in second and third phases of growth of Mahanadi delta indicated that Neo tectonic activity is high and there are chances of getting fossil fuels like oil and gas beneath them. 


\section{International Journal of Science and Research (IJSR) \\ ISSN (Online): 2319-7064}

Index Copernicus Value (2013): 6.14 | Impact Factor (2014): 5.611

\section{Characteristics of Mahanadi Delta}

a) The Mahanadi delta is asymmetrical inform. The asymmetrical growth of delta is identified by uneven progradation of the delta in each stage of development with reference to the apex.

b) The fluvial process is dominated over coastal process. The anastamosing nature of ancient channels and abandoned meander lobes show major shifts in river courses as the delta is built up.

c) The beach ridges are formed almost parallel or sub parallel to one another in each strandline. In the central part of delta the beach ridges might have been washed away due to later fluvial process.

d) Largely the NE-SW, ENE-WSW and NW-SE lineament trends are noticed. Some of the old River and present river courses are controlled by macro lineaments. A macro lineament running NE-SW direction for about $240 \mathrm{~km}$ is responsible for deposition of sediments to a depth of about $4 \mathrm{~km}$ in the eastern and north-eastern part of the delta.

e) The geomorphic highs or morphostructures are prominent in the second and third stages of growth of the delta along and near to the former delta fronts.

\section{Evolution of the modern Mahanadi Delta:}

The evolution of the modern deltas have been studied by Niyogi ${ }^{17}, \mathrm{Babu}^{3}$, Nageswara Rao and Vaidyanadhan ${ }^{14}$, Sambasiva Rao etal. ${ }^{23}$, Sambasiva Rao and Vaidyanadhan ${ }^{24}$, Sambasiva Rao ${ }^{20,21,22}$ and Sambasiva Rao and Lakshminarayana $^{25}$. Russel ${ }^{19}$ and Guilcher ${ }^{9}$ have generalized that shifting of river courses is a major phenomenon in the deltaic evolution.

The evolution of the modern Mahanadi delta has been brought out from the disposition of ancient channels and ancient beach ridges. Basing on alignment and spread of ancient channels and ancient beach ridges the successive phases in the growth of abandoned meander lobes and delta fronts are identified. The following inferences are made in the growth of Mahanadi delta.

1) Basing on disposition of beach ridges three strandlines/former delta fronts have been identified. The first delta front is about $35 \mathrm{Km}$ away from the present shoreline. The second delta front is about $19 \mathrm{Km}$ away from the present shoreline. The third delta front is about $7 \mathrm{Km}$ from the present shoreline. The number of beach ridges have increased from first to third delta fronts and average altitude has receded from 6.77 meters from first delta front to 3 meters in the third delta front.( Fig.2)

2) About 23 abandoned meander lobes are identified basing on anastamosing ancient channels of the Mahanadi delta. Similarly 23 paleo confluences and paleo lagoons are identified at the confluence points of the former 23 abandoned meander lobes.

3) In the first stage of growth of Mahanadi delta two abandoned meander lobes are recognized. The direction of flow of the first abandoned meander lobe is NW-SE and the second one is ENE-WSW direction. The length of first abandoned meander lobe is $49.7 \mathrm{Km}$ and the maximum width is $1.65 \mathrm{Km}$ (Table.3). The length of second abandoned meander lobe is $56.8 \mathrm{Km}$ and the maximum width is $7.1 \mathrm{Km}$. Each abandoned meander lobe has one paleo confluence each. The distance from present shoreline is about $35 \mathrm{Km}$.

4) In the second stage of growth of Mahanadi delta the River Mahanadi was flowing with eleven abandoned meander lobes. The direction of flow was N-S (one abandoned meander lobe), NW-SE (six abandoned meander lobes), E-W (three abandoned meander lobes) and NE-SW (one abandoned meander lobe). The maximum width varies from $7.00 \mathrm{KM}$ to $12.0 \mathrm{Km}$ and maximum length ranges from $35.50 \mathrm{Km}$ to $74.50 \mathrm{Km}$ (Table. III). There were eleven paleo confluences and eleven paleo lagoons at the then confluence points of the abandoned meander lobes. The maximum distance from the present shoreline is about $19 \mathrm{Km}$.

5) During the third stage of growth of Mahanadi delta the River Mahanadi was flowing with ten abandoned meander lobes. The direction of flow was N-S (one abandoned meander lobe), NE-SW (two abandoned meander lobes), E-W (one abandoned meander lobe) and NW-SE (six abandoned meander lobes). The maximum width of abandoned meander lobes vary from $2.85 \mathrm{KM}$ to $7.1 \mathrm{Km}$ and maximum length ranges from $49.70 \mathrm{Km}$ to $78.10 \mathrm{Km}$ (Table. III). There were ten paleo confluences and ten paleo lagoons at the then confluence points of the abandoned meander lobes. The maximum distance from the present shoreline is about $7 \mathrm{Km}$.

6) At present the River Mahanadi debouches into Bay of Bengal through two major distributaries namely Mahanadi River and Devi River and four minor distributaries namely Daya, Bhargavi, Kushbhandra and Prachi Nadi.

7) It is noticed from the disposition of abandoned meander lobes that the growth of modern Mahanadi delta is NWSE, NNW-SSE, E-W and NE-SW. The arcuate shape of the Mahanadi delta is found in second, third and present stages of the growth of the Mahanadi delta.

Morphological variations in the evolution of major deltas of the east coast of India.

A) Sambasiva Rao (1979) and Sambasiva Rao and Vaidyanadhan (1979) have described that there is symmetrical growth in the modern Godavari delta with four delta fronts and ten abandoned meander lobes.

B) Nageswara Rao and Vaidyanadhan (1978) and Nageswara Rao (1980) have identified ten abandoned meander lobes and five delta fronts in the growth of modern Krishna delta.

C) Sambasiva Rao (1982) has recognized twelve abandoned meander lobes and three major delta fronts in the growth of modern Cauvery delta.

D) Sambasiva Rao and Lakshminarayana (2007) have identified ten abandoned meander lobes and three major delta fronts of Pennar delta.

E) Sambasiva Rao (2013) has demarcated eight abandoned meander lobes and four delta fronts in the growth of Brahmani and Baitrani delta.

F) There seems to be similarities in the growth of Cauvery, Pennar and Mahanadi deltas. The three deltas are dominated by fluvial proceses.

G) The extent of oldest shoreline lies $35 \mathrm{Km}$ away from the present shoreline in all the deltas.

H) The shifts of old river courses were uneven in Godavari and Krishna deltas. 


\section{International Journal of Science and Research (IJSR) \\ ISSN (Online): 2319-7064}

Index Copernicus Value (2013): 6.14 | Impact Factor (2014): 5.611

I) The shifts of old river courses were from south to north in the Cauvery delta and Pennar delta.

J) The shifts of old river courses were NW-SE, NNW-SSE, E-W and NE-SW in the Mahanadi delta.

\section{Age of the Modern Mahanadi delta:}

Basing on $\mathrm{C}^{14}$ dating of Oolite sample from a deep marine core sediment collected from $200 \mathrm{Km}$ NE of Kakinada Naidu (1968) has suggested that there was a lowering of sea level due to glaciations of the East coast of India around $10,800 \pm 150$ year B.P. Mallick, Bhattacharya and Niyogi (1972) have concluded that Chandbali formations were formed during the last 6,000 years B.P. The Post Pleistocene rise of the sea level has been dated by C-14 method by different scientists in other parts of the world and concluded that the rise of sea level could have taken place between 18,000 years to 4,000 years B.P. Bernard and Leblane (1965) have concluded that the sea level during the Post Pleistocene period has been stabilized at the present position by about 6,000 years B.P. Basing on Bernard and Leblane (1965) and Jelgersma (1966) sea level curve and $C^{14}$ dating of molluscan shells it is inferred that first series from beach ridges in the Mahanadi delta might have been from 6,000 years to 3,500 years B.P. The second beach formed ridges could have been formed from 3,500 years to 2,100 years B.P. and third series of beach ridges might have been formed from 2,100 year to 1,000 years B.P. This does not preclude to the delta forms and sediments beneath the modern delta, being much older in age.

\section{Rate of Progradation}

The modern Mahanadi delta might have been formed after restoration of sea level around $10,800 \pm 155$ years B.P as suggested by Naidu (1968). The deeper sedimentary formations are much older and the modern sediments formations are found up to 20 meters depth. The average length of delta from the apex to the present shoreline is about $91 \mathrm{Km}$. The rate of progradation of modern Mahanadi delta would be about $9.1 \mathrm{Km}$ for one thousand years. The rate of progradation of some of world deltas is

a) $20 \mathrm{Km} / 1000$ years, Mississippi delta in USA, Scruton (1960).

b) $8.5 \mathrm{Km} / 1000$ years, Po River delta in Italy, Nelson (1970).

c) $2 \mathrm{Km} / 1000$ years Sehyan delta in Turkey, Evans (1973).

d) $3.5 \mathrm{Km} / 1000$ years Rhone delta in France, Okmans (1970).

e) $20 \mathrm{Km} / 1000$ years, Orinoco delta in Venezuela, Van Andel (1967).

f) $40 \mathrm{Km}$ to $50 \mathrm{Km} / 1000$ years, Tigris Euphrates delta in Iraq, Larsen and Evans (1978).

The rate of progradation of modern deltas of the East coast of India are

a) Ganga delta $30 \mathrm{Km} / 1000$ years, Babu (1972)

b) Subernarekha delta $3.5 \mathrm{Km} / 1000$ years, Niyogi (1968)

c) Brahmani-Baitarani delta $7.7 \mathrm{Km} / 1000$ years, Sambasiva Rao (2013)

d) Mahanadi delta $9.1 \mathrm{Km} / 1000$ years

e) Godavari delta $7.25 \mathrm{Km} / 1000$ years, Sambasiva Rao (1979) f) Krishna delta $7.5 \mathrm{Km} / 1000$ years, Nageswara Rao and Vaidyanadhan (1978)

g) Pennar delta $4.5 \mathrm{Km} / 1000$ years, Sambasiva Rao and Lakshminarayana (2010) and

h) Cauvery delta 10 Km/1000 years, Sambasiva Rao (1982).

\section{Conclusions}

The Mahanadi delta is largely comprised of ancient channels and beach ridges. Basing on disposition, direction, altitude and number of beach ridges about three former delta fronts have been identified. Basing on deposition, alignment, direction of flow and former confluence points at former delta front or ancient strandline about 23 abandoned meander lobes have been demarcated. The paleo confluences and paleo lagoons are identified. Largely NE-SE and NWSE trends of lineaments are found. Basing on disposition of strandlines and abandoned meander lobes the overall growth of the modern Mahanadi delta has been described. Like other modern delta of the East coast of India the modern Mahanadi delta is presumed to be formed during Holocene period. The rate of growth of Mahanadi delta is $9.1 \mathrm{~km}$ per thousand years.

\section{References}

[1] Babu, P.V.L.P. (1972): A review on geomorphological studies around the Hooghly delta - Bengal Basin. Proc. Seminar on Geomorphology, Geohydrology and Geotectonic of Ganga basin. IIT,Kharagpur, West Bengal.pp 1-6.

[2] Babu, P.V.L.P. (1973): Morphostructures of Krishna and Godavari delta region. Photonirvanchak (Jour Indi.Society. Photointer.) Vol I (1-2), pp.65-67.

[3] Babu, P.V.L.P. (1975): Morphological evolution of Krishna delta. Ibid Vol.3 (1), pp.21-27.

[4] Babu, P.V.L.P. (1978): Geomorphology of the KrishnaGodavari delta region. Interpreted from landsat imagery. The National Geographical Journal of India. Special issue 24, pp. 55-65.

[5] Bagchi. K (1994): The Ganges delta. Calcutta University Publication, Culcutta, pp.157.

[6] Bernard, H.A and Le Balane, R.J (1965): Resume of Quaternary geology of the Northwestern Gulf of Mexico Province; Quat.USA

[7] Evans, G (1973): Recent coastal sedimentation: A review. In Marine Archaeology (Ed. Black man, D.J.) pp. 89-144.

[8] Fairbridge, R.W. (1968): The Encyclopedia of Geomorphology Encyclopedia of Earth Science. Vol. 3, Reinhold Book Corporation, New York. Pp. 731.

[9] Guilcher, A. (1963): Estruaries, Deltas, Shelf, Slope. In The Sea (Ed. Hill, M.N.) Interscience Publication, New York, Vol. 3, Ch. 24, pp.620-654.

[10] Jelgerma, S. (1966): Sea level changes during the last 10,000 years. J.S. Sawyer (ed) World climate from 8,000 years B.C to O.B.C. London Metrological Society, pp. 44-69.

[11]Larsen, E.C. and Evans, G (1978): The Holocene geological history of Tigris Euphrates Delta. In the Historical Geography of Middle East (Ed. Brice,w.) Academic press. Inc, pp. 227-244. 


\section{International Journal of Science and Research (IJSR) \\ ISSN (Online): 2319-7064 \\ Index Copernicus Value (2013): 6.14 | Impact Factor (2014): 5.611}

[12] Meijerink, A.M.J. (1971): Reconnaissance survey of the Quaternary Geology of the Caurvey delta. Journ. Geol.Soc. India 12, pp. 113-124.

[13] Morgan, G.T andW,G.Mc.Intyre (1959): Quaternary Geology of the Bengal Basin, East Pakistan and India. Geol.Soc.Amer.Bull70, pp.319-342.

[14] Nageswara Rao, K and R. Vaidyanadhan (1978): Geomorphic features in Krishna delta and its evolution. Symposium on Morphology and Evolution of Landforms. Dept.of Geology, University of Delhi, New Delhi, pp. 121-130.

[15] Naidu, A.S (1968): Some aspects of texture, mineralogy and geochemistry of modern deltaic sediments of Godavari river. Unpubl. PhD thesis submitted to Andhra University, Waltair, India. Pp.250.

[16] Nelson, B.W. (1978): Hydrography,Sediment disprersal and recent historical development of Po River delta, Italy. In deltaic sedimentation, modern and ancient (Ed. Morgan, J.P.) Spec. Pub Soc. Eco, Palegon Minero Tulsa 15 pp.152-184.

[17] Niyogi, D. (1968): Morphology and evolution of Subarnarekha delta, India. Saertryk of Geogr Tidsskrift, 67, pp. 230-241.

[18] Okmans (1970): Depositional sequence and sand distribution in Post Glacial Rhone delta complex. Spec. Pub Soc. Eco Pale Minero Tulsa 15, pp. 198-212.

[19] Russel, R. J. (1942): Geomorphology of the Rhone delta. Annals Assoc. of American Geographers 32(2) pp.149-254.

[20] Sambasiva Rao M (1979): Geomorphology and evolution of the modern Godavari delta, Andhra
Pradesh, India. Unpublished Ph.D Thesis submitted to Andhra University, waltair, pp.150.

[21] Sambasiva Rao M (1982): Morphology and Evolution of the modern Cauvery delta, Tamil Nadu Inia. Trans. Insti. Indian Geographers Vol.4 No.1, pp 67-78.

[22] Sambasiva Rao M (2013): Geomorphology and Evolution of the Modern Brahmani Baitarani delta, Eastern Geographer, Vol.XIX, pp. 20-27.

[23] Sambasiva Rao M, K. Nageswar Rao and R. Vaidyanadhan (1978): Morphology and Evolution of Mahanadi and, Brahmani Baitarani deltas, Symposium on Morphology and Evolution of Landforms, Dept. of Geology, University of Delhi, New Delhi. Pp. 241-249.

[24] Sambasiva Rao M and R. Vaidyanadhan (1979): Morphology and evolution of the modern Godavari delta, India. Z. Geomorph N.F: 23(3) pp. 243-255.

[25] Sambasiva Rao M and S. Lakshminarayana (2007): Geomorphology and evolution of the Modern Pennar delta, Andhra Pradesh, India. Eastern Geographer Vol.XIII No.1, pp.12-19.

[26] Scruton, P.C. (1960): Delta building and deltaic sequence; In Recent sediments of Northwest of Mexico (Eds. Stiepard F.P.F. B.Phileger and Andel T.H. Van) American Association of Petroleum Geological Bulletin, pp 82-102.

[27] Van Andel T.H. (1967): The Orinoco delta. Journ Sedi Petrol, 37 (2) pp. 297-310.

[28] Wright, L.D. and J. Coleman (1973): Variations in Morphology of major deltas as functions of ocean waves and river discharge regimes. Am Assoc. Petrol. Geol. Bull. 57(2), pp. 370-398.

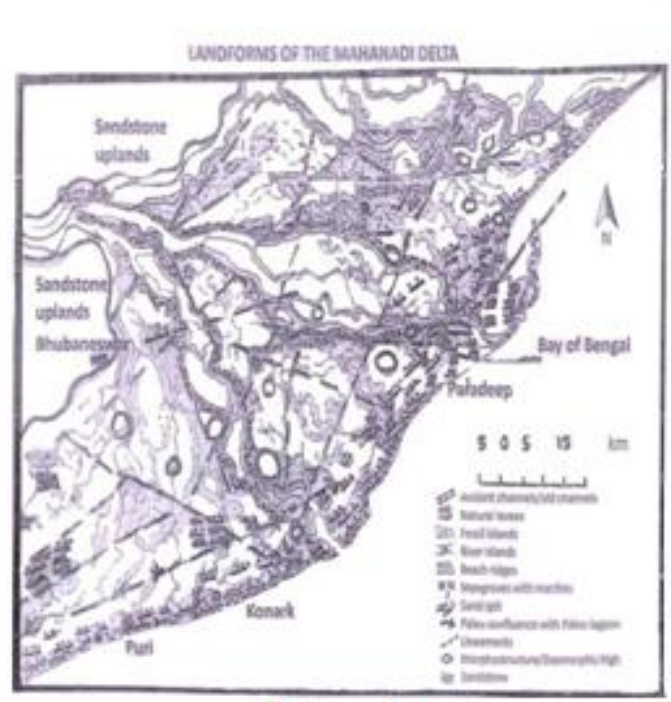

Figure 1

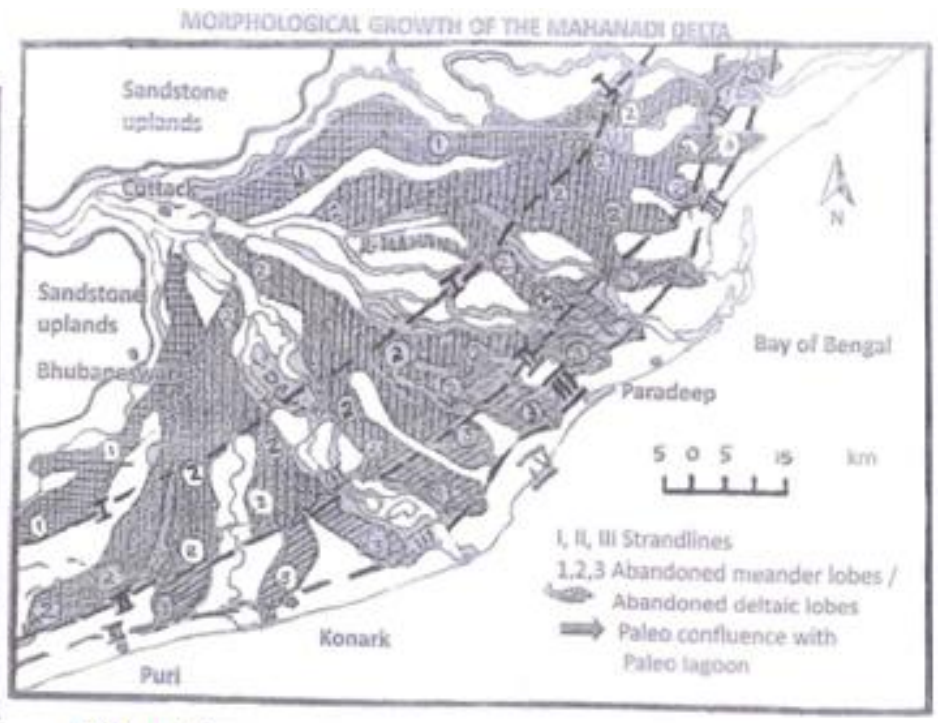

Figure 2

Table 1: Beach Ridges of the Mahanadi Delta

\begin{tabular}{|c|c|c|c|c|c|c|c|c|c|}
\hline S. no & Strandline & Location & $\begin{array}{c}\text { Max.Distance } \\
\text { from present } \\
\text { shoreline in km }\end{array}$ & $\begin{array}{c}\text { No.of Beach } \\
\text { Ridges }\end{array}$ & $\begin{array}{c}\text { Width in } \\
\mathrm{km}\end{array}$ & Direction & $\begin{array}{c}\text { Maximum } \\
\text { height in } \\
\text { meters }\end{array}$ & $\begin{array}{c}\text { Minimum } \\
\text { height in } \\
\text { meters }\end{array}$ & $\begin{array}{c}\text { Average } \\
\text { height in } \\
\text { meters }\end{array}$ \\
\hline 1 & I & Ghordia & 35 & 3 to 5 & 3 & E-W & 8.2 & 5.5 & 6.77 \\
\hline 2 & II & NW of Puri & 19 & 4 to 6 & 5 & ENE-WSW & 5.9 & 3.5 & 5.2 \\
\hline 3 & III & Puri \& Konarak & 7 & 5 to 8 & 7 & ENE,WSW & 4.5 & 1.5 & 3 \\
\hline 4 & IV & \multicolumn{2}{|c|}{ Present Shoreline is bordered by sand dunes } & MSL & MSL & \\
\hline
\end{tabular}


International Journal of Science and Research (IJSR)

ISSN (Online): 2319-7064

Index Copernicus Value (2013): 6.14 | Impact Factor (2014): 5.611

Table 2: Lineament Analysis of the Mahanadi Delta

\begin{tabular}{|c|c|c|c|c|}
\hline S. No & Direction & Class internal in 10 degrees & No.of lineaments & Cumulative length in Km \\
\hline 1 & N-E & $0-10$ & 2 & 46.9 \\
\hline 2 & N-E & $10-20$ & 1 & 52.50 \\
\hline 3 & N-E & $20-30$ & 2 & 108.5 \\
\hline 4 & N-E & $30-40$ & 2 & 45.5 \\
\hline 5 & N-E & $40-50$ & 3 & 113.80 \\
\hline 6 & N-E & $50-60$ & 1 & 23.50 \\
\hline 7 & N-E & $60-70$ & 2 & 44.00 \\
\hline 8 & N-E & $70-80$ & - & - \\
\hline 9 & N-E & $80-90$ & - & 434.7 \\
\hline 10 & N-W & $0-10$ & 3 & 7.0 \\
\hline 11 & N-W & $10-20$ & 1 & 43.0 \\
\hline 12 & N-W & $20-30$ & 1 & - \\
\hline 13 & N-W & $30-40$ & - & \\
\hline
\end{tabular}

Table 3: Abandoned Meander Lobes of the Mahanadi Delta

\begin{tabular}{|c|c|c|c|c|c|}
\hline S. No & Stage & $\begin{array}{c}\text { Direction of abandoned } \\
\text { meander lobe }\end{array}$ & $\begin{array}{c}\text { Maximum width of abandoned } \\
\text { meander lobe in km }\end{array}$ & $\begin{array}{l}\text { Length of abandoned } \\
\text { meander lobes in } \mathrm{km}\end{array}$ & $\begin{array}{l}\text { No.of paleo } \\
\text { confluences }\end{array}$ \\
\hline 1 & I & NW-SE & 10.65 & 49.7 & One \\
\hline 2 & & ENE-WSW & 7.1 & 56.8 & One \\
\hline \multirow[t]{11}{*}{3} & II & NW-SE & 12 & 56.2 & One \\
\hline & & NW-SE & 7.0 & 39 & One \\
\hline & & $\mathrm{N}-\mathrm{S}$ & 8.5 & 35.5 & One \\
\hline & & NW-SE & 10.65 & 39 & One \\
\hline & & NW-SE & 7.1 & 39.05 & One \\
\hline & & NW-SE & 8.52 & 44.7 & One \\
\hline & & E-W & 7.1 & 35.7 & One \\
\hline & & NW-SE & 7 & 39.05 & One \\
\hline & & E-W & 10.65 & 49.7 & One \\
\hline & & E-W & 7.1 & 54 & One \\
\hline & & NE-SW & 7.0 & 74.5 & One \\
\hline \multirow[t]{10}{*}{3} & III & $\mathrm{N}-\mathrm{S}$ & 7.0 & 53.3 & One \\
\hline & & NE-SW & 5.70 & 49.7 & One \\
\hline & & NW-SE & 4.2 & 49.8 & One \\
\hline & & NW-SE & 6.4 & 53.2 & One \\
\hline & & NW-SE & 5.7 & 51.1 & One \\
\hline & & NW-SE & 7.1 & 53.25 & One \\
\hline & & NW-SE & 4.9 & 56.8 & One \\
\hline & & NE-SW & 2.85 & 53 & One \\
\hline & & E-W & 4.25 & 63.9 & One \\
\hline & & NW-SE & 3.5 & 78.1 & One \\
\hline
\end{tabular}

Volume 5 Issue 2, February 2016 